\title{
ENTOMOLOGY
}

\section{Monitoring of Aedes albopictus (Skuse) (Diptera, Culicidae) in the city of Catania (Italy): seasonal dynamics and habitat preferences}

\author{
S. Bella, ${ }^{1}$ A. Russo, ${ }^{2}$ P. Suma ${ }^{2}$ \\ ${ }^{1}$ CREA-OFA - Consiglio per la Ricerca in Agricoltura e l'analisi dell'economia Agraria, Centro di Ricerca \\ Olivicoltura, Frutticoltura e Agrumicoltura, Acireale (CT); ${ }^{2}$ Dipartimento di Agricoltura, Alimentazione e Ambiente, \\ Entomologia Applicata, Università degli Studi di Catania, Italy
}

\begin{abstract}
Estimated seasonal abundance of the Asian tiger mosquito, Aedes albopictus (Skuse, 1894) (Diptera, Culicidae) in the municipality of Catania (eastern Sicily, Italy) is provided and discussed. A monitoring campaign was carried out in urban and suburban sectors of the city during the autumn of 2007 and all of 2008 and 2013. Populations of the mosquito were surveyed weekly with standard ovitraps as a tool for estimating its population density. Analysis of the distributional data, seasonal occurrence, habitat preferences, and egg-laying intensity of the mosquito is provided.
\end{abstract}

\section{Introduction}

Over the last 30 years, seven alien mosquitoes (Diptera, Culicidae) have been found in Europe (Kenis \& Branco, 2010)

\footnotetext{
Correspondence: Salvatore Bella, CREA-OFA Consiglio per la ricerca in agricoltura e l'analisi dell'economia agraria, Centro di ricerca olivicoltura, frutticoltura e agrumicoltura, Corso Savoia 190, 95024 Acireale (CT), Italy.

Tel.: +39.095.7653153. E-mail: salvatore.bella@crea.gov.it
}

Key words: Asian tiger mosquito, invasive mosquito, eggs density, Mediterranean region.

Contributions: the authors contributed equally.

Conflict of interests: the authors declare no potential conflict of interests.

Funding: none.

Received for publication: 5 December 2017

Revision received: 30 April 2018.

Accepted for publication: 30 April 2018.

CCopyright S. Bella et al., 2018

Licensee PAGEPress, Italy

Journal of Entomological and Acarological Research 2018; 50:7217 doi:10.4081/jear:2018.7217

This article is distributed under the terms of the Creative Commons Attribution Noncommercial License (by-nc 4.0) which permits any noncommercial use, distribution, and reproduction in any medium, provided the original author(s) and source are credited. and, among the genus Aedes, the following species have been intercepted: Aedes aegypti (Linnaeus, 1762), A. albopictus (Skuse, 1894), A. atropalpus (Coquillett, 1902), A. japonicus (Theobald, 1901), A. koreicus Edwards, 1917, and A. triseriatus (Say, 1823) (DAISIE, 2018; ECDC, 2018).

During this last decade, preeminent importance has been devoted to the Asian tiger mosquito, Aedes albopictus (Diptera, Culicidae), in relation of its threatened capability to human health. This species, native to tropical and subtropical forests in southeastern Asia, has spread from its original areas to most countries in all continents through shipments of used tires (Romi, 2001; Severini et al., 2009). Dispersal capabilities (passive transport) of adults of this species in cars and trucks have been recently confirmed and investigated by Eritja et al. (2017). Aedes albopictus is well adapted to a temperate climate and has already invaded a large part of southern Europe and is now spreading northwards (Cunze et al., 2016). The diffusion of the Asian tiger mosquito in Europe has raised serious concerns due to its possible role in the transmission of viruses (Flaviviridae: Flavivirus) and filarial nematodes (Onchocercidae: Spirurida) (Masetti et al., 2008; Romi et al., 2009a). Nematodes Dirofilaria immitis (Leidy) and $D$. repens (Raillet \& Henry) are the etiological agents of canine heartworm and dog subcutaneous granulomas, respectively; both species can cause parasitic zoonosis: accidental infections in humans may result in subcutaneous, conjunctival, and pulmonary nodules (Pampiglione et al., 2001). This species is a vector of exotic disease agents introduced through the circulation of infected humans and animals, e.g. many arboviruses such as Dengue, Yellow fever, West Nile, and Chikungunya (Romi et al., 2009b). From 2004, this mosquito has become the principal vector in a large epidemic of Chikungunya fever in tropical Asia and Africa (Enserink, 2007; Weeratunga et al., 2017).

After nearly 20 years in Italy, A. albopictus was responsible for the first Chikungunya virus (Togaviridae, gen. Alphavirus) epidemic in Europe (Bonilauri et al., 2008) in 2007 in the Emilia-Romagna region, causing more than 250 human cases of a febrile illness with benign outcome (Rezza et al., 2007). More recently, in the autumn of 2017 , other autochthonous infection cases of Chikungunya have been ascertained in Italy in the cities of Anzio and Rome in the Latium region and in the town of Guardavalle Marina in the Calabria region. In the European Union, in addition to Italy, only France has reported outbreaks of indigenous cases of Chikungunya in the past (i.e. in 2010, 2014, and 2017) (Fortuna, 2017). Infections of D. immitis have been reported for natural populations of $A$. albopictus in central and 
northern Italy (Cancrini et al., 2003a,b; Cancrini et al., 2007), and confirmation of the role of $A$. albopictus in the circulation of dog heartworm in Italy (northern regions) was provided by Masetti et al. (2008). More recently, specimens of A. albopictus from different areas of Italy were found infected with the West Nile virus, the causative agent of a zoonosis that is also becoming common in the country (Rizzo et al., 2009).

The aim of our study was to evaluate the seasonal abundance of the Asian tiger mosquito in the municipality of Catania (eastern coast of Sicily, Italy) through oviposition responses to standard ovitraps during all seasons of the year.

\section{Diffusion of Aedes albopictus in Italy}

The first record of $A$. albopictus in Italy was in the city of Genoa (Sabatini et al., 1990), followed a year later in Padua (Dalla Pozza \& Majori, 1992). The colonisation of Padua was caused by the arrival of one or more loads of infested tires from the United States of America, and in fact all the Italian populations have a high genetic affinity to those from the United States and Japan (Dalla Pozza et al., 1994). The rapid spread of A. albopictus in Italy is probably the result of several successive introductions, each with large numbers of individuals (Romi et al., 1999; Urbanelli et al., 2000). The Asian tiger mosquito in Italy spread first in the Po Valley (especially in the northeastern sector); it then continued in the direction of Bologna and then Florence, to the centre of Italy, first colonising the Tyrrhenian coast (Knudsen et al., 1996; Romi, 2001), then the Adriatic coast, and finally entering southern Italy and Sicily (Romi, 2005). Stable colonies of $A$. albopictus have been identified in Italy since the early 1990s (Sabatini et al., 1990; Dalla Pozza \& Majori, 1992; Romi 1994). The species is currently present in all regions of Italy (Severini et al., 2009; Romi et al., 2012). It was recorded in Sardinia for the first time in the city of Cagliari in 1994-95, (Romi, 1995; Nuvoli \& Pantaleoni, 2003), but the prompt intervention of the local public-health agency eradicated the introduced population. In autumn 2006, the Asian tiger mosquito was detected again on islands in the two port cities, Cagliari and Olbia (Cristo et al., 2006). A. albopic- tus was recorded for the first time in Sicily in 2003, in the city of Palermo (Liotta \& Matranga, 2004).

\section{Materials and Methods}

Field observations were conducted in the urban and suburban areas of Catania in the autumn of 2007 and subsequently for all of 2008 and 2013. In 2007, ovitraps were allocated in ten sectors of the municipality (Figure 1), while in 2008 and 2013, A. albopictus was monitored only in the sector with the highest peaks of the population in 2007 (Table 1). The monitoring used standard ovitraps (Celli et al., 1994; Bellini et al., 1996), consisting of a black conic plastic cup ( $\sim 00 \mathrm{ml}$ capacity, upper diameter $8 \mathrm{~cm}$, lower diameter $6 \mathrm{~cm}$ ) filled $2 / 3$ with water $(\sim 300 \mathrm{ml})$, with a masonite strip $(12.5 \times 2.5 \mathrm{~cm})$ fastened to the inner edge to provide a suitable surface for oviposition (Albieri et al., 2010). A small hole above the water level (300 ml) prevented the cups from being completely filled with water after a rain, which would reduce the ovipositional surface to zero.

Three ovipositional traps were placed in each station investigated during 2007 (for a total of 30 ovitraps) separated by at least $100 \mathrm{~m}$. Ovitraps were placed in shaded sites, at ground level, and with free space above them of at least $50 \mathrm{~cm}$. Two ovitraps were placed in the monitored sector in 2008 and 2013, which remained in the same location all year, one in microhabitat conditions of partial shade at the base of a citrus tree, the other with the same microhabitat conditions but in contact with a building. The distance between the two ovitraps was $20 \mathrm{~m}$. The masonite strips with $A$. albopictus eggs were collected weekly, individually protected in transparent plastic bags, labelled (date, trap, and sample number), and brought to the laboratory for counting the eggs under a stereomicroscope. After each check, the masonite strip and water were replaced, and the ovitraps were washed with water.

Data on weather conditions (average weekly temperature) were recorded at the Fontanarossa meteorological station (weather station 228 Catania, 37.263006 N, 15.4322 E).

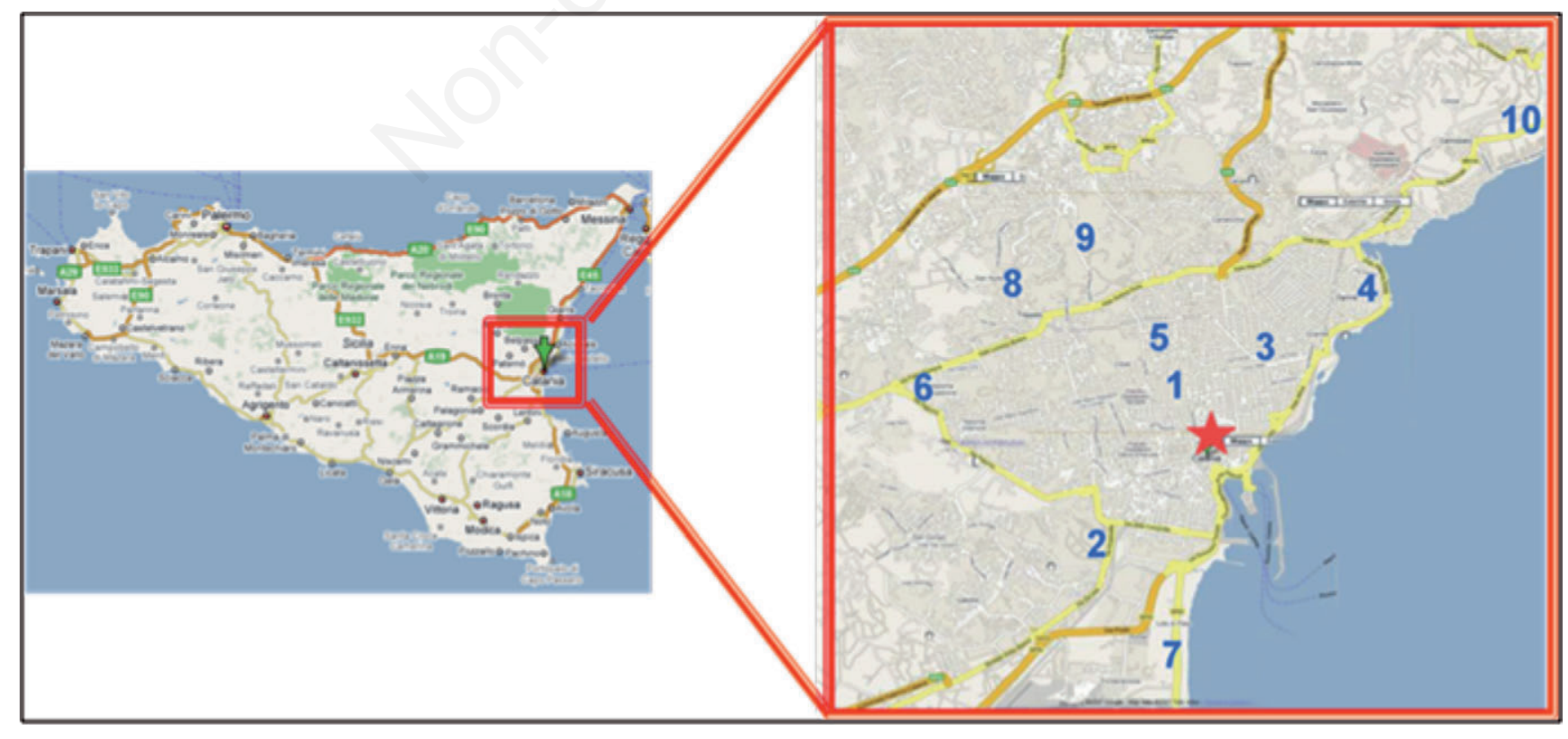

Figure 1. City map of Catania showing the ten sites investigated (ovitrap positions) in 2007. 


\section{Sampling sites}

In the autumn of 2007, ovitraps were allocated in ten sectors of the municipality in urban areas with high population concentrations (sites I, III, and V), suburban areas (sites IV, VI, VIII, and IX), and semirural areas (sites II, VII, and X) (Figure 1). The data for egg density collected by the ovitraps in the 2007 season were used to assess the mosquito populations and to identify the area of the city with an increased presence of the mosquito for monitoring in subsequent years. Some of the sites were chosen because they represented preferred habitats in human environments, as reported in previous studies (Bartlett-Healy et al., 2012; Bonacci et al., 2014), such as nurseries (site IV), cemeteries (site II), public and private parks, and gardens (sites I, V, VII, and VIII) (Table 1). The ovitraps were placed in an altitudinal range varying from sea level to $110 \mathrm{~m}$ a.s.l. In 2011 and 2013, ovitraps were positioned in optimal microhabitat conditions: green, semi-shaded positions, as defined in Bartlett-Healy et al. (2012), and Crepeau et al. (2013), easily accessible on the ground, with an upper free space of about $50 \mathrm{~cm}$, and were maintained unchanged until the end of the flight season and throughout the two years of investigation.

\section{Results}

Our field data showed that the presence of A. albopictus in the city of Catania remained at worrisome levels for most of the year. This species, due to favourable climatic conditions in Sicily, not only in the hottest months of the year, was also abundant in late autumn and, although with lower density, also in spring. In fact, the mosquito was absent only from December to March. At the beginning of the investigation in 2007, the mosquitoes were absent from only three of the ten sectors in the cities affected by the census (III, VI, and VIII) (Figure 2).

In the 2007 season, the largest number of eggs was detected at site V (old citrus orchard) (Figure 2). It was located in a dense residential district in the north of the city and featured large gardens. This confirmed the findings of other authors of the preference of this species for green areas, mostly with the presence of trees for increased populations (Crepeau et al., 2013). At site V, judging by the number of eggs, they followed the ovitraps allocated to sites VII (Boschetto Playa) and X (Nursery), about 100 and $300 \mathrm{~m}$ from the coast, respectively. Both areas were characterised by extensive plant cover, trees at site VII and shrubs at site X (Figures 3 and 4).

In the following two years of monitoring, in 2008 and 2013,

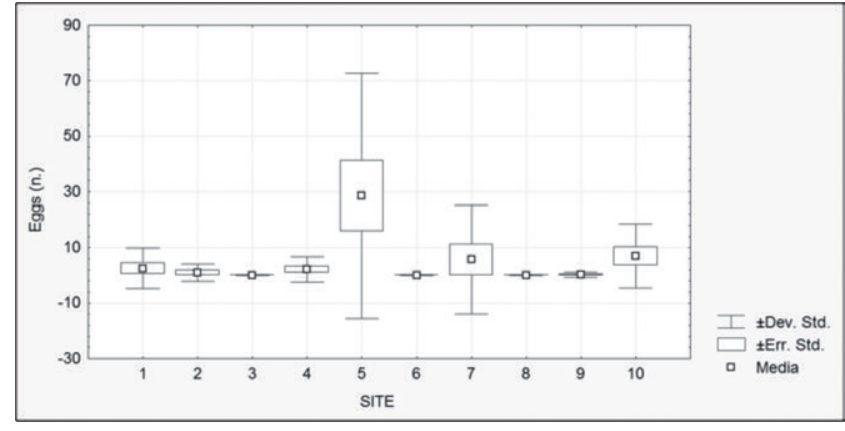

Figure 2. Mean number of eggs of $A$. albopictus, layed in the selected sites during 2007.

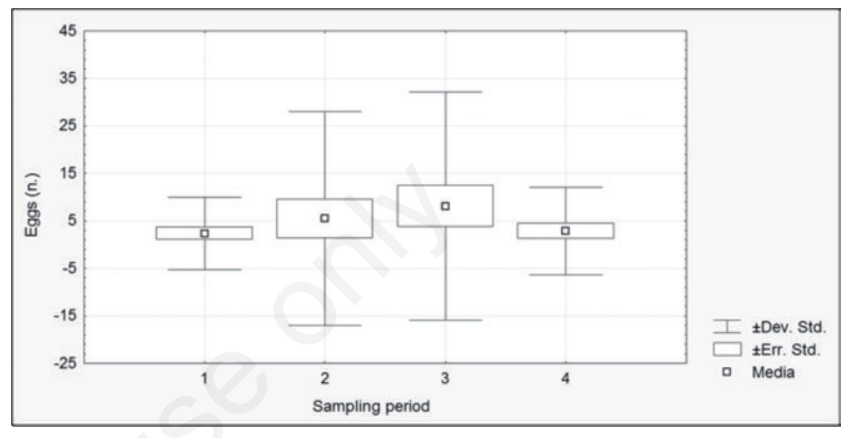

Figure 3. Mean number of eggs of $A$. albopictus layed during the four sampling period carried out in 2007.

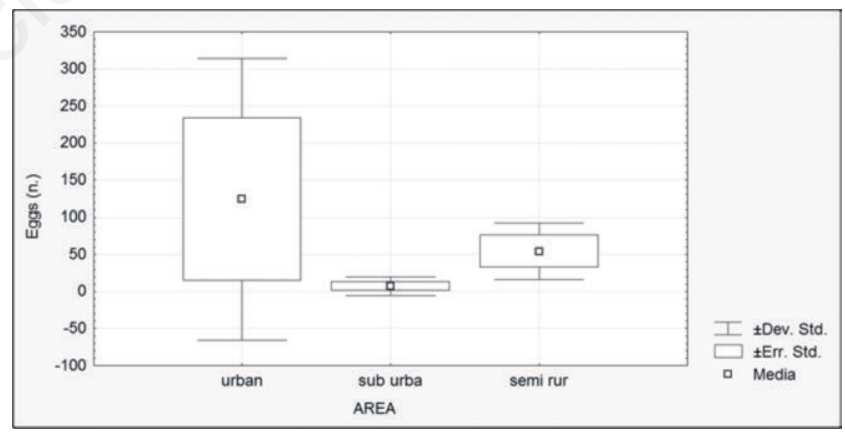

Figure 4. Mean number of eggs of $A$. albopictus, layed in the ovitraps in the three different areas considered in 2007.

Table 1. Code traps, area where the traps were positioned and number of traps allocated per site.

\begin{tabular}{lllll} 
Code trap & Sites & Localities & Zone of city & No. traps \\
I & Bellini garden & via Etnea & Urban area/Central sector & 3 \\
II & Cemetery & via Acquicella & Urban area/South-West sector & 3 \\
\hline III & Primary school & corso Italia & Urban area/Central sector & 3 \\
IV & Ognina & via Messina & Suburban/North-East sector & 3 \\
\hline V & Old Citrus orchard & Cibali & Urban area/North sector & 3 \\
VI & Nesima superiore & via Palermo & Suburban/West sector & 3 \\
\hline VII & Boschetto Playa & viale Kennedy & Suburban/South sector & 3 \\
VIII & Parco degli ulivi & San Nullo & Suburban/North-West sector & 3 \\
\hline IX & Agrarian Faculty & via Santa Sofia & North sector & 3 \\
X & Nursery & Cannizzaro & Suburban/North-East sector & 3 \\
\hline
\end{tabular}


surveys continued only at site $\mathrm{V}$, which had the largest number of eggs in 2007. The difference in preference in microhabitat by $A$. albopictus for oviposition was evident in fact, in both years of the investigation, the preference was for the ovitrap positioned at the base of the tree compared to the other with the same microhabitat but in contact with a building (Figures 5 and 6).

As Figures 5 and 6 show, the start and end of the life cycle of A. albopictus coincided both in 2008 and 2013, and oviposition began from the third week of April, with weekly temperatures of $17-18^{\circ} \mathrm{C}$ in both years; in the cold season, however, the end of the life cycle was in the third week of November in 2008 and in the second week of November in 2013, with average weekly temperatures of $14^{\circ} \mathrm{C}$ in both years.

In the two years of investigation, the main peak of ovideposition was recorded at different times of the year (Figures 5 and 6), between the third week of June and the second of July (average weekly temperatures of $23-30^{\circ} \mathrm{C}$ ) and between the second week of September and the second of October (average weekly temperatures of $19-22^{\circ} \mathrm{C}$ ).

The total number of eggs deposited over the two years was noticeably different (Figure 7). In fact, the number of eggs deposited in 2008 was 3947 in the tree ovitrap and 1828 in the building trap; in 2013, there was a net increase, 7365 in the tree ovitrap and 1702 in the building trap.

\section{Discussion and Conclusions}

Good surveillance is the foundation of informative field epidemiology and effective programmes to control vectors or nuisance mosquitoes (Romi et al., 2009a). About 25 years after the first finding of A. albopictus in Italy, the phenology of the species was well-known (Romi et al., 2012); in fact, the flight time runs from February-March to October-November in the various regions depending on latitude and seasonal climate change.

Mosquito control is mainly directed against larvae and, only if necessary, against adults. Bacillus thuringiensis israelensis (Bti) has good larvicidal activity (Weeratunga et al., 2017) and is often used because it is considered to be harmless to humans and other non-dipteran insects. Unfortunately, the insecticidal activity of Bti is lost after 24 hours, and it is completely ineffective against eggs and pupal stages of A. albopictus (Macchioni et al., 2008). There is a need to develop efficient and eco-sustainable control, that must take into account the possible occurrence of insecticide resistance tools (Medlock et al., 2015). Eritja et al. (2005) reported that the suitable areas for $A$. albopictus must have: i) mean rainfall more than $500 \mathrm{~mm}$ per year, ii) more than 60 rainy days $(0.1 \mathrm{~mm}$ rainfall minimum each) per year, and iii) mean yearly temperatures higher than $11^{\circ} \mathrm{C}$. Catania's climate satisfies the requirements of temperature and mean rainfall per year but is at the limit for the number of rainy days per year (on average 56 days).

In the field trials, the ovitraps were effective in attracting ovipositing A. albopictus. The data from the ten sites investigated were useful for the study of abundance, distribution, ecological preferences, and fluctuations in A. albopictus infestations in different areas of the city of Catania and in all seasons of the year. Data on changes in infestation in the urban and suburban areas of the city were in line with those for other Italian cities (Celli et al., 1994; Romi, 1995; Nuvoli \& Pantaleoni, 2003; Toma et al., 2003; Brianti et al., 2008; Severini et al., 2008; Bonacci et al., 2014) and were related to the presence of optimal environmental conditions such as temperature, air humidity, large green and shady spaces, and availability of water of anthropic origin.
In the areas of the planet where A. albopictus has arrived, numerous biotic and abiotic factors have been investigated in an attempt to identify variables associated with the productivity of the species (Bueno-Marí \& Jiménez-Peydró, 2015). In the northeastern United States, Bartlett-Healy et al. (2012), based on pupal abundance and container types, showed that tires, trash cans, and planter dishes were the most important containers for A. albopictus oviposition, and black and grey were the container colours that played a role in the selection of sites by females. Significant differ-

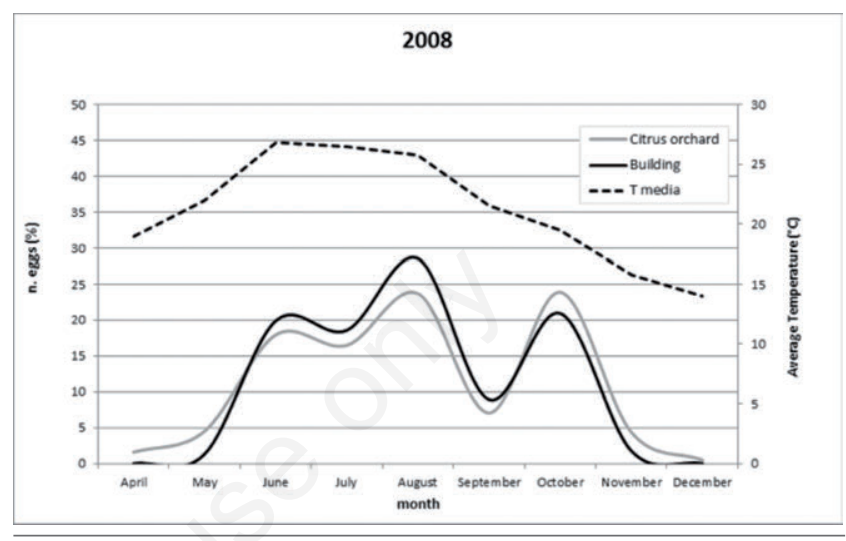

Figure 5. Oviposition trend of $A$. albopictus during 2008.

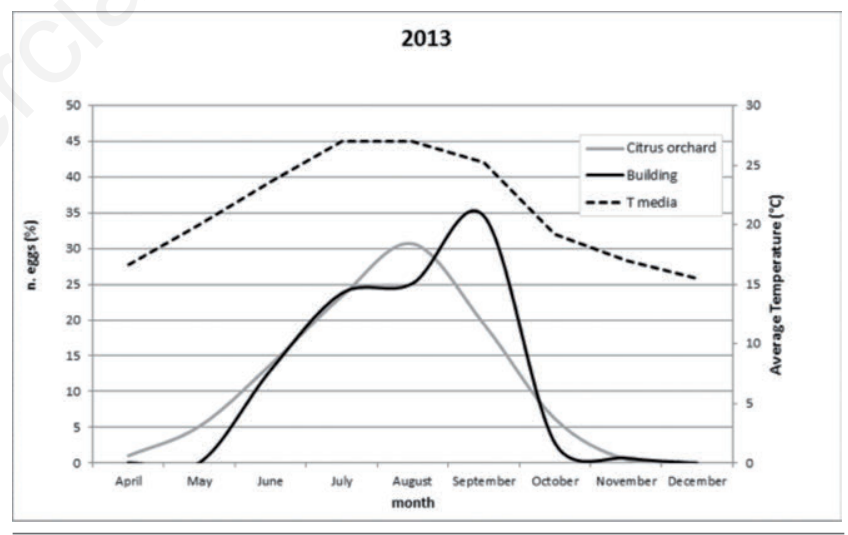

Figure 6. Oviposition trend of $A$. albopictus during 2013.

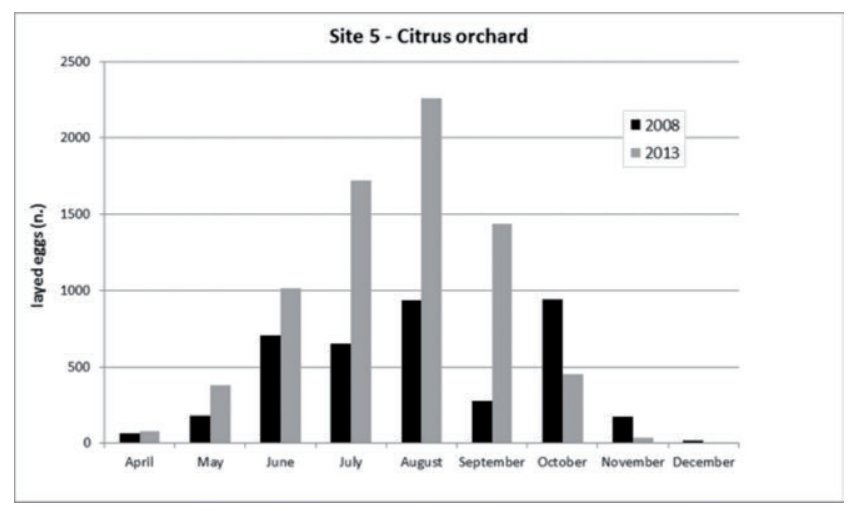

Figure 7. Oviposition trend of $A$. albopictus throughout the two years of investigation. 
ences in abundance of the species were also detected between urban, suburban, and rural areas: A. albopictus was much more abundant in urban and suburban habitats.

The control programs for invasive species need to have standards in data collecting and data analysis in order to compare results for different ecological and geographical sites (Suma et al., 2014; Nejati et al., 2017). The new statistical analysis of monitoring data of $A$. albopictus proposed by Mazzei et al. (2014) that considered the effort of sampling to estimate seasonal abundance to the mosquito is thus interesting. Considering the primary role in recent Dengue and Chikungunya outbreaks that makes $A$. albopictus a very important public-health threat throughout the world, and in function of its particular ecological plasticity (e.g. in terms of larval breeding sites, feeding behavior, and climatic adaptation), it is easy to comprehend the importance of a better understanding and of monitoring the spread of this species throughout our country in order to limit the expansion of its range and impact on human health.

\section{References}

ALBIERI A., CARRIERI M., ANGELINI P., BALDACCHINI F., VENTURELLI C., MASCALI ZEO S., BELLINI R., 2010 Quantitative monitoring of Aedes albopictus in EmiliaRomagna, Northern Italy: cluster investigation and geostatistical analysis. - Bull. Insectol. 63: 209-216.

BARTLETT-HEALY K., UNLU I., OBENAUER P., HUGHES T., HEALY S., CREPEAU T., FARAJOLLAHI A., KESAVARAJU B., FONSECA D., SCHOELER G., GAUGLER R., STRICKMAN D., 2012 - Larval mosquito habitat utilization and community dynamics of Aedes albopictus and Aedes japonicus (Diptera: Culicidae). - J. Med. Entomol. 49: 813-824.

BELLINI R., CARRIERI M., BURGIO G., BACCHI M., 1996 Efficacy of different ovitraps and binomial sampling in Aedes albopictus surveillance activity. - J. Am. Mosq. Contr. Assoc. 12: 632-636.

BONACCI T., MAZZEI A., SCALERCIO S., PERRELLI M., BELLUSCI A., VALENTINI I., BRANDMAYR P., 2014 - Primi dati sul monitoraggio di Aedes albopictus (Skuse 1894) (Diptera, Culicidae) a Cosenza e Rende. - XXIV Congresso Nazionale di Entomologia, Orosei, (Sardegna), 9-14 giugno 2014.

BONILAURI P., BELLINI R., CALZOLARI M., ANGELINI R., VENTURI L., FALLACARA F., CORDIOLI P., ANGELINI P., VENTURELLI C., MERIALDI G., DOTTORI M., 2008 Chikungunya virus in Aedes albopictus, Italy. - Emerg. Infect. Dis. 14: 852-853.

BRIANTI E., FERLAZZO M., INTERDONATO M., GIANNETTO S., 2008 - A two-years monitoring of Aedes albopictus (Diptera, Culicidae) in the city of Messina. - Parassitologia 50: 1-2.

BUENO-MARÍ R., JIMÉNEZ-PEYDRÓ R., 2015 - First observations of homodynamic populations of Aedes albopictus (Skuse) in Southwest Europe. - J. Vector Borne Dis. 52: 175-177.

CANCRINI G., FRANGIPANE DI REGALBONO A., RICCI I., TESSARIN C., GABRIELLI S., PIETROBELLI M., 2003a Aedes albopictus is a natural vector of Dirofilaria immitis in Italy. - Vet. Parasitol. 118: 195-202.

CANCRINI G., ROMI R., GABRIELLI S., TOMA L., SCARAMOZZINO P., 2003b - First finding of Dirofilaria repens in a natural population of Aedes albopictus. - Med. Vet. Entomol. 17: 448-451.

CANCRINI G., SCARAMOZZINO P., GABRIELLI S., DI PAOLO M., ROMI R., 2007 - Aedes albopictus and Culex pip- iens implicated as natural vectors of Dirofilaria repens in Central Italy. - J. Med. Entomol. 44: 1064-1066.

CELLI G., BELLINI R., CARRIERI M., 1994 - Survey on Aedes albopictus (Skuse) (Diptera: Culicidae) infestation in Desenzano del Garda (Brescia province - Italy). - Bollettino dell'Istituto di Entomologia "Guido Grandi" della Università di Bologna, 48: 211-217.

CREPEAU T.N., HEALY S.P., BARTLETT-HEALY K., UNLU I., FARAJOLLAHI A., FONSECA D.M., 2013 - Effects of biogents sentinel trap field placement on capture rates of adult Asian Tiger Mosquitoes, Aedes albopictus. - PLoS ONE 8: e60524.

CRISTO B., LORU L., SASSU A., PANTALEONI R.A., 2006 The Asian tiger mosquito again in Sardinia. - Bull. Insectol. 59: 161-162.

CUNZE S., KOCHMANN J., KOCH L.K., KLIMPEL S., 2016 Aedes albopictus and its environmental limits in Europe. PLoS ONE 11: e0162116.

DAISIE, 2018 - Delivering Alien Invasive Species Inventories for Europe. - www.europe-aliens.org.

DALLA POZZA G.L., MAJORI G., 1992 - First record of Aedes albopictus establishment in Italy. - J. Am. Mosq. Contr. Assoc. 8: 318-320.

DALLA POZZA G.L., ROMI R., SEVERINI C., 1994 - Source and spread of Aedes albopictus in the Veneto region, Italy. - J. Am. Mosq. Contr. Assoc. 10: 589-592.

ECDC, 2018 - Mosquito factsheets. - https://ecdc.europa.eu/en/disease-vectors/facts/mosquito-factsheets/aedes.

ENSERINK M., 2007 - Infectious diseases. Chikungunya: no longer a third world disease. - Science 318: 1860-1861.

ERITJA R., ESCOSA R., LUCIENTES J., MARQUES E., ROIZ D., RUIZ S., 2005 - Worldwide invasion of vector mosquitoes: present European distribution and challenges for Spain. - Biol. Invas. 7: 87-97.

ERITJA R., PALMER J.R.B., ROIZ D., SANPERA-CALBET I., BARTUMEUS F., 2017 - Direct evidence of adult Aedes albopictus dispersal by car. - Sci. Rep. 7: 14399.

FORTUNA C., 2017 - Rischi di importazione e diffusione di infezioni virali trasmesse da vettori in Italia: epidemia di Chikungunya. - http://www.izs.it/IZS/Engine/RAServeFile.php.

KENIS M., BRANCO M., 2010 - Chapter 5: Impact of alien terrestrial arthropods in Europe. In: Roques A. et al. (Eds). Alien terrestrial arthropods of Europe. - BioRisk 4: 51-71.

KNUDSEN A.B., ROMI R., MAJORI G., 1996 - Occurrence and spread in Italy of Aedes albopictus, with implications for its introduction into other parts of Europe. - J. Am. Mosq. Contr. Assoc. 12: 177-183.

LIOTTA G., MATRANGA G., 2004 - La Zanzara tigre è arrivata in Sicilia. - Igiene Alimenti, Disinfestazione \& Igiene Ambientale, 21: 49-50.

MACCHIONI F., SICILIANO T., MAGI M., CECCHI F., CIONI P.L., BRACA A., 2008 - Activity of aqueous extract of Panax notoginseng flower buds against Aedes albopictus larvae and pupae. - Bull. Insectol. 61: 31-35.

MASETTI A., RIVASI F., BELLINI R., 2008 - Mosquito-based survey for the detection of flaviviruses and filarial nematodes in Aedes albopictus and other anthropophilic mosquitoes collected in northern Italy. - New Microbiologica 31: 457-465.

MAZZEI A., BRANDMAYR P., SCALERCIO S., NOVELLO M.G., BONACCI T., 2014 - Nuova metodologia di analisi dei dati di monitoraggio di Aedes albopictus (Skuse, 1894) (Diptera Culicidae). - Nat. Sic., S. IV, XXXVIII: 103-111.

MEDLOCK J.M., HANSFORD K.M., VERSTEIRT V., CULL B., KAMPEN H., FONTENILLE D., HENDRICKX G., ZELLER 
H., VAN BORTEL W., SCHAFFNER F., 2015 - An entomological review of invasive mosquitoes in Europe. - Bull. Entomol. Res. 105: 637-663.

NEJATI J., BUENO-MARÍ R., COLLANTES F., HANAFI-BOJD A.A., VATANDOOST H., CHARRAHY Z., TABATABAEI S.M., YAGHOOBI-ERSHADI M.R., HASANZEHI A., SHIRZADI M.R., MOOSA-KAZEMI S.H., SEDAGHAT M.M., 2017 - Potential risk areas of Aedes albopictus in SouthEastern Iran: a vector of Dengue Fever, Zika, and Chikungunya. - Front. Microbiol. 8: 1660.

NUVOLI M.T., PANTALEONI R.A., 2003 - La zanzara tigre in Sardegna: storia di un quinquennio di caccia, pp. 18-29. In: Le acque, l'uomo, la storia, il territorio (Piga G.S., Ed.). Associazione Sas Amoradas, Romana, Sassari, Italy.

PAMPIGLIONE S., RIVASI F., ANGELI G., BOLDORINI R., INCENSATI R.M., PASTORMERLO M., PAVESI M., RAMPONI A., 2001 - Dirofilariasis due to Dirofilaria repens in Italy, an emergent zoonosis: report of 60 new cases. Histopathology 38: 344-354.

REZZA G., NICOLETTI L., ANGELINI R., ROMI R., FINARELLI A.C., PANNING M., CORDIOLI P., FORTUNA C., BOROS S., MAGURANO F., SILVI G., ANGELINI P., DOTTORI M., CIUFOLINI M.G., MAJORI G.C., CASSONE A., 2007 - Infection with chikungunya virus in Italy: an outbreak in a temperate region. - Lancet 370: 1840-1846.

RIZZO C., VESCIO F., DECLICH S., FINARELLI A.C., MACINI P., MATTAVI A., ROSSINI G., PIOVESAN C., BARZON L., PALU G., GOBBI F., MACCHI L., PAVAN A., MUAGURANO F., CIUFOLINI M.G., NICOLETTI L., SALMASO S., REZZA G., 2009 - West Nile virus transmission with human cases in Italy, August-September 2009. - Euro Surv. 14: 19353.

ROMI R., 1994 - Aedes albopictus in Italia: problemi sanitari, strategie di controllo e aggiornamento della distribuzione. Notiziario dell'Istituto Superiore di Sanità, 7: 7-11.

ROMI R., 1995 - History and updating on the spread of Aedes albopictus in Italy. - Parassitologia, 37: 99-103.

ROMI R., 2001 - Aedes albopictus in Italia: un problema sottovalutato. - Annali dell'Istituto Superiore di Sanità, 37 : 241-248.

ROMI R., 2005 - La gestione delle infestazioni da Zanzara tigre. Igiene Alimenti, Disinfestazione \& Igiene Ambientale, 22: 36-40.
ROMI R., DI LUCA M., MAJORI G., 1999 - Current status of Aedes albopictus and Aedes atropalpus in Italy. - J. Am. Mosq. Contr. Assoc. 15: 425-447.

ROMI R., KHOURY C., BIANCHI R., SEVERINI F. (Ed.), 2012 - Artropodi di interesse sanitario in Italia e in Europa. - Roma: Istituto Superiore di Sanità (Rapporti ISTISAN 12/41).

ROMI R., TOMA L., SEVERINI F., DI LUCA M., 2009a - 20 years of presence of Aedes albopictus in Italy: from the annoying pest mosquito to the real diseases vector. - Eur. Infect. Dis. 2: 98-101.

ROMI R., TOMA L., SEVERINI F., DI LUCA M., BOCCOLINI D., CIUFOLINI M.G., NICOLETTI L., MAJORI G., 2009b Linee guida per il controllo di Culicidi potenziali vettori di arbovirus in Italia. - Istituto Superiore di Sanità, Roma.

SABATINI A., RAINIERI V., TROVATO G., COLUZZI M., 1990 - Aedes albopictus in Italia e possibile diffusione della specie nell'area mediterranea. - Parassitologia 32: 301-304.

SEVERINI F., DI LUCA M., TOMA L., ROMI R., 2008 - Aedes albopictus in Rome: results and perspectives after 10 years of monitoring. - Parassitologia 50: 121-123.

SEVERINI F., TOMA L., DI LUCA M., ROMI R., 2009 - Le ZANZARE ITALIANE: generalità e identificazione degli adulti (Diptera, Culicidae). - Fragm. Entomol. 41: 213-372.

SUMA P., NUCIFORA S., BELLA S., 2014 - New distribution record of the invasive bronze bug Thaumastocoris peregrinus Carpintero and Dellapé (Heteroptera, Thaumastocoridae) in Italy. - Bulletin OEPP/EPPO 44: 179-182.

TOMA L., SEVERINI F., DI LUCA M., BELLA A., ROMI R., 2003 - Seasonal patterns of oviposition and egg hatching rate of Aedes albopictus in Rome. - J. Am. Mosq. Contr. Assoc. 19: 19-22.

URBANELLI S., BELLINI R., CARRIERI M., SALLICANDRO P., CELLI G., 2000 - Population structure of Aedes albopictus (Skuse): the mosquito which is colonizing Mediterranean countries. - Heredity 84: 331-337.

WEERATUNGA P., RODRIGO C., FERNANDO S.D., RAJAPAKSE S., 2017 - Control methods for Aedes albopictus and Aedes aegypti (Protocol). - Cochrane Database of Systematic Reviews 8: CD012759. 